UNDERGRADUATE RESEARCH IN NATURAL AND CLINICAL SCIENCE AND TECHNOLOGY (URNCST) JOURNAL Read more URNCST Journal articles and submit your own today at: https://www.urncst.com

\title{
Developing a Method to Determine Salivary THC Concentration
}

Alina He, BSc Student [1]*, Marina Nysten, BSc Student [2], Farida Rahman, BSc Student [3], Joyce Wu, BSc Student [4]

[1] Neuroscience Program, McGill University, Montreal, Quebec, Canada H3A 0G4

[2] Department of Physiology, McGill University, Montreal, Quebec, Canada H3A 0G4

[3] Department of Biology, McGill University, Montreal, Quebec, Canada H3A 0G4

[4] Department of Psychology, McGill University, Montreal, Quebec, Canada H3A 0G4

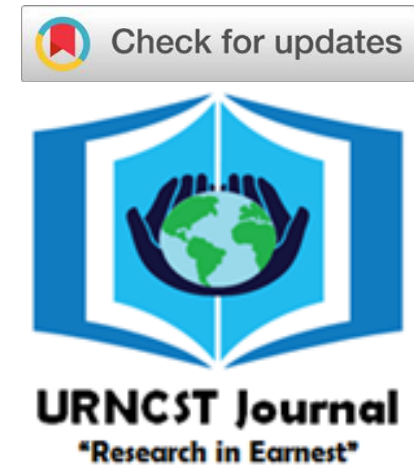

*Corresponding Author: alina.he@mail.mcgill.ca

\begin{abstract}
Introduction: Cannabis impairs cognitive and psychomotor performance, which can negatively affect driving skills. The main psychoactive ingredient in cannabis is $\Delta 9$-tetrahydrocannabinol (THC). Due to the recent legalization of cannabis in Canada, there is an urgent need for a roadside test to identify THC impaired drivers. The legal limit while driving is calculated based on blood THC concentration, but saliva samples are the most convenient to collect roadside. Thus, the objectives of this study are to (1) determine the relationship between salivary and serum THC concentration and (2) develop a suitable roadside method to determine salivary THC concentration.

Methods: THC doses between $0.2 \mathrm{mg} / \mathrm{Kg}$ to $100 \mathrm{mg} / \mathrm{Kg}$ will be orally administered to 36 mice ( 18 female, 18 male) in a repeatedmeasures design. Saliva and blood samples will be collected in 15 min intervals from 0 to 6 hours after administration. Gas chromatography (GC) and liquid chromatography (LC) coupled to mass spectrometry (MS) will be used to determine THC concentration in the saliva and blood samples. The relationship between salivary and serum THC concentration will be modelled. In addition, a series of azo dyes will be applied to the saliva samples to determine salivary THC concentrations in a simple and rapid manner. The samples will be dissolved in $\mathrm{NaOH}$, and various dyes will be added. An acid-base reaction will create a phenolate anion from the phenolic group of the $\Delta 9$-THC molecule, which will then attack the diazo group of the azo dye to produce a coloured end-product.

Expected Results: We expect a positive linear relationship between the logged salivary and blood serum THC concentrations. We predict that each azo dye will produce a single colour within a specific and different range of THC concentration, so a distinct set of colours produced from many dyes can be associated with a narrow range of salivary THC concentration.

Discussion: The colours produced from the azo dye reactions can be associated with salivary THC concentrations, which can then be correlated to serum THC concentrations. We use a mouse model in this study to have a more controlled investigation of the relationship between salivary and serum THC concentration, but future investigations should apply the results to humans.

Conclusion: This study aims to determine salivary THC concentration in a suitable roadside method and correlate the results to serum THC concentration. The implications of this study are to be able to detect THC impaired drivers in a simple and rapid manner.
\end{abstract}

Keywords: azo dyes; impaired driving; roadside testing; salivary THC concentration; serum THC concentration

\section{Introduction}

Cannabis impairs cognitive and psychomotor performance, which can negatively affect driving skills [1]. Cannabis use is associated with an increased risk of being involved in traffic accidents [2]. The main psychoactive ingredient in cannabis is $\Delta 9$-tetrahydrocannabinol (THC) [3]. The recent legalization of cannabis in Canada will likely increase the number of people who will drive under the influence of cannabis. Thus, it is critical to have a reliable roadside test to identify THC impaired drivers. Police officers currently identify THC impaired drivers using visual diagnostics, like red eyes and muscle tremors, as well as standardized field sobriety tests $[4,5]$. However, these tests

He et al. | URNCST Journal (2020): Volume 4, Issue 3

DOI Link: https://doi.org/10.26685/urncst.177 are highly subjective, as they rely on the officers' qualitative judgments. There is a device, the Draeger DrugTest 5000, that has been approved by the Canadian government for roadside testing of THC in saliva samples [6]. The Draeger DrugTest 5000 uses immunological assay technology to determine THC concentration in oral fluids [7]. This test has many reported limitations. A study that analyzed this device concluded it has a high rate of false positives (13.4\%) and false negatives (14.5\%) [7]. Additionally, temperature restrictions on the machine limit its use to between $4^{\circ} \mathrm{C}$ and $40^{\circ} \mathrm{C}$, which is impractical for Canadian winters [6]. Lastly, the device has a low sensitivity for THC concentrations below $5 \mathrm{ng} / \mathrm{mL}$ [7]. Therefore, there is a need to develop a 
UNDERGRADUATE RESEARCH IN NATURAL AND CLINICAL SCIENCE AND TECHNOLOGY (URNCST) JOURNAL Read more URNCST Journal articles and submit your own today at: $\underline{\text { https://www.urnest.com }}$

test that is more suitable for roadside use to identify THC impaired drivers.

The current legal limit for blood THC concentration while driving is $2 \mathrm{ng} / \mathrm{mL}$ [8]. Blood THC concentrations above $2 \mathrm{ng} / \mathrm{mL}$ are fined, while concentrations above $5 \mathrm{ng} / \mathrm{mL}$ are charged as a criminal offense [8]. Although the limit is in terms of blood THC concentration, saliva samples are the most convenient to collect roadside. Previous studies have reported a positive linear correlation between salivary $\log [\mathrm{THC}]$ and serum $\log [\mathrm{THC}]$ levels in humans, but reports on the strength of the relationship are inconsistent $[2,9]$. Thus, it would be useful to have a better understanding of the relationship between salivary and serum THC concentration.

Azo dyes have been used as a simple and rapid method of determining the presence of cannabis in saliva samples [10]. There are many azo dyes that produce a different colour upon reacting with cannabis [11]. A previous study developed a proposed mechanism for the reaction between $\triangle 9$-THC and the Fast Blue Salt B (FBBBS) azo dye. The first step is an acid-base reaction between the phenolic group of the $\triangle 9$-THC molecule and the basic medium $(\mathrm{NaOH})$ that the sample and azo dye are dissolved in [12]. This results in a phenolate ion, which then attacks the diazo group of the FBBBS molecule [12]. Consequently, a tautomerization of the non-aromatic intermediate produces the end products - a protonated ion $\left[\mathrm{C}_{38} \mathrm{H}_{47} \mathrm{~N}_{3} \mathrm{O}_{5}+\mathrm{H}\right]^{+}$and a sodium adduct $\left[\mathrm{C}_{38} \mathrm{H}_{47} \mathrm{~N}_{3} \mathrm{O}_{5}+\mathrm{Na}\right]^{+}$[12]. Previous studies that have assessed these azo dye reactions have inconsistent conclusions about their specificity in detecting the presence of marijuana in that some conclude it is specific enough, while others disagree $[12,13]$. Due to the simplicity, speed, and low cost of this method, it would be beneficial to further investigate their potential use in the detection of cannabis. We want to see whether these different dyes will react at distinct THC concentration ranges. We propose to (1) investigate the relationship between salivary and serum THC concentrations and (2) determine whether azo dyes can be used to accurately determine salivary THC concentration in a mouse model. This study would allow for the development of an efficient method of determining THC concentrations from saliva samples taken roadside and their corresponding serum THC concentrations, which can then be compared to the legal limit.

\section{Methods \\ Animals \\ Male and female mice will be kept on a 12-hour light/dark cycle at room temperature. Food and water will be available ad libitum.}

\section{Drug Dose and Administration}

THC will be dissolved in oil and force fed. Based on previous studies, THC doses ranging from $0.2 \mathrm{mg} / \mathrm{Kg}$ to $100 \mathrm{mg} / \mathrm{Kg}$ will be used [3]. We will administer doses of 0.2 , $1,5,10,50$, or $100 \mathrm{mg} / \mathrm{Kg}$ of THC to 36 mice (18 female, 18 male) in a repeated-measures design. Saliva and blood

He et al. | URNCST Journal (2020): Volume 4, Issue 3 DOI Link: https://doi.org/10.26685/urncst.177 samples will be collected at $15 \mathrm{~min}$ intervals from 0 to 6 hours after THC administration [2]. Saliva samples will be collected using cannulation of the submandibular gland after pilocarpine stimulation [14].

\section{Measurement of THC Concentration in Saliva and Blood Samples}

Gas chromatography (GC) and liquid chromatography (LC) coupled with mass spectrometry (MS) will be used to determine the salivary and serum THC concentrations $[9,15]$. This method has an accuracy of $95 \%$ to $97 \%$, with reliable detection of THC concentrations above $1 \mathrm{ng} / \mathrm{mL}$ [16]. The relationship between salivary and serum THC concentration will be modelled using linear regression, similar to previous studies $[9,15]$.

Determination of Salivary THC Concentrations using Azo Dyes Although mass spectrometry has a high accuracy, it is inconvenient for roadside testing. Applying a series of azo dyes to saliva samples is potentially a simple and rapid method to determine the THC concentration of saliva samples taken roadside. Each azo dye produces a single colour upon reacting with cannabis [11]. For instance, the most common colorimetric test for the detection of cannabis uses the fast blue B dye (FBBS), which produces a red colour [12]. It is unclear if these dyes will react at specific and different THC concentrations. A series of azo dyes (diazo red $\mathrm{RC}$, blue $\mathrm{B}$, brown $\mathrm{V}$, Corinth $\mathrm{LB}$, garnet GBC, orange GC, red FRN) will be applied to saliva samples with known THC concentrations, as determined using GC-MS and LCMS [11]. The following protocol has been adapted from Maunder (1969). One $\mathrm{mL}$ of saliva will be placed on absorbent paper. After, 1 drop of petroleum ether will be added. The liquid should have sufficient time to soak into the paper and dry. The substance will be removed from the paper. Then, $0.1 \mathrm{mg}$ of diluted azo dye (1:100 dilution with solid anhydrous sodium sulfate) will be placed on the absorbent paper. Finally, 1 drop of water will be added. [11]. This reaction will be repeated for many azo dyes that produce a different colour upon reacting with cannabis at potentially different THC concentrations. The relationship between the distinct set of colours produced and salivary THC concentrations will be determined. Note the variation in colour intensity is likely not a reliable indicator of THC concentration. We are examining the presence or absence of specific colours at different THC concentrations. Subsequently, the colours will be analyzed using a spectrophotometer. The premise is similar to determining $\mathrm{pH}$ using various $\mathrm{pH}$ indicators.

Finally, the accuracy of this method will be tested using saliva and blood samples with THC concentrations that were not previously used to determine their relationship. A series of azo dyes will be applied to the saliva samples to estimate the salivary THC concentrations and corresponding serum THC concentrations based on their relationship. The 
UNDERGRADUATE RESEARCH IN NATURAL AND CLINICAL SCIENCE AND TECHNOLOGY (URNCST) JOURNAL Read more URNCST Journal articles and submit your own today at: https://www.urncst.com

accuracy of the azo dyes in determining salivary THC concentration can be assessed by comparing the salivary THC concentrations estimated by the dyes and the salivary THC concentrations determined using GC-MS and LC-MS. The predictive ability of the relationship between salivary and serum THC concentration can be assessed by comparing the serum THC concentrations correlated with the given salivary THC concentrations identified from the azo dye test and the serum THC concentrations determined using GC-MS and LC-MS.

\section{Expected Results}

Relationship between Salivary and Serum THC Concentration

We anticipate that there will be a positive linear correlation for salivary $\log [\mathrm{THC}]$ and serum $\log [\mathrm{THC}]$ based on previous human studies [2, 9]. We also expect this relationship to be independent of the time of sampling after drug use, as a previous study found salivary THC concentrations were consistently higher than serum THC concentrations, but the ratio of salivary to serum THC concentration remained relatively constant during the elimination phase [2]. Similar correlations between THC levels in saliva and blood have been reported in other studies using controlled THC administration [17] and drug users [18]. Huestis and Cone gave low and high-dose cannabis cigarettes to male subjects with a history of cannabis use [17]. Oral and blood samples were taken over a 24 hour period and analyzed with GC-MS [17]. Samyn and Van Haeren used roadside tests on drivers that exhibited impaired behavior who consented to taking part in the study [18]. Saliva and blood samples were taken among other samples and analyzed using the Drugwipe device and GC-MS [18].

\section{Associating a Distinct Set of Colours with Salivary THC Concentrations}

We hypothesize that the azo dyes will react at specific and different THC concentrations. If each azo dye produces a single colour within a specific and different range of $\mathrm{THC}$ concentration, and this reaction is repeated for many dyes, then each narrow range of salivary THC concentration can be associated with a distinct set of colours. The specific colours produced associated with salivary THC concentration can then be correlated with serum THC concentration based on their relationship. This procedure will likely not associate colours to a specific $\mathrm{THC}$ concentration, but rather a narrow range of $\mathrm{THC}$ concentration. For the purpose of roadside detection, identifying a narrow range of $\mathrm{THC}$ concentration is sufficient, as long as concentrations above and below the legal threshold are clearly distinguishable.

\section{Discussion}

In this study, we aim to develop a simple and rapid method suitable for roadside testing to identify THC impaired drivers. To do this, we first confirm the correlation between salivary and serum THC concentration. Some studies have

He et al. | URNCST Journal (2020): Volume 4, Issue 3 DOI Link: https://doi.org/10.26685/urncst.177 reported this relationship in humans $[2,9]$, but here we use mice to have controlled THC administration with limited confounding variables to additionally determine the distinct set of colours associated with salivary THC concentrations produced from azo dye reactions. In human studies, there are more confounding variables, including time of drug use and individual variation in physiological response. The colours produced can be associated with a narrow range of salivary THC concentration and subsequently with serum THC concentrations.

If the relationship between salivary and serum THC concentration is similar in mice and humans, there will also be a positive linear correlation between salivary $\log [\mathrm{THC}]$ and serum $\log [\mathrm{THC}]$. However, the strength of this relationship will likely be higher in this study than it would be in samples taken roadside. Previous studies done on samples taken from impaired drivers show a weaker correlation between salivary and serum THC concentration than studies done in a controlled laboratory setting $[2,9]$. This means the results from this study may not be as clearly demonstrated in samples obtained from impaired drivers. However, the first steps to developing a reliable method to determine salivary THC concentration should be done in a more controlled setting. A future direction would be to apply this procedure to human participants.

\section{Conclusions}

This study aims to correlate salivary and serum THC concentration and to determine salivary THC concentration using a suitable roadside method. It is hypothesized that there is a positive linear correlation between salivary $\log [\mathrm{THC}]$ and serum $\log [\mathrm{THC}]$. We propose using a series of azo dye reactions to associate a distinct set of colours with narrow ranges of THC concentration in saliva samples, which can then be correlated to serum THC concentrations. This procedure can be used to determine if a driver has reached or exceeded the legal threshold of blood THC concentration. This study has the potential to improve roadside detection of THC impaired driving by developing a simple, fast, and low-cost method to determine salivary THC concentration. Rodent studies allow for a more controlled exploration of this method, but ultimately, it is important to apply this procedure to humans.

\section{List of Abbreviations}

THC: $\Delta$ 9-tetrahydrocannabinol

LC: Liquid chromatography

GC: Gas chromatography

MS: Mass spectrometry

\section{Conflicts of Interest}

The authors declare that they have no conflict of interest.

Ethics Approval and/or Participant Consent

This was a research protocol and no ethics approval was obtained. 
UNDERGRADUATE RESEARCH IN NATURAL AND CLINICAL SCIENCE AND TECHNOLOGY (URNCST) JOURNAL Read more URNCST Journal articles and submit your own today at: https://www.urncst.com

\section{Authors' Contributions}

AH: made substantial contributions to the design of the study, drafted and revised the manuscript critically, and gave final approval of the version to be published.

MN: made substantial contributions to the design of the study, drafted and revised the manuscript critically, and gave final approval of the version to be published.

FR: made substantial contributions to the design of the study, drafted and revised the manuscript critically, and gave final approval of the version to be published.

JW: made substantial contributions to the design of the study, drafted and revised the manuscript critically, and gave final approval of the version to be published.

\section{Funding}

This study was not funded.

\section{References}

[1] Bondallaz P, Favrat B, Chtioui H, Fornari E, Maeder P, Giroud C. Cannabis and its effects on driving skills.

Forensic Science International. 2016 Nov;

268: 92-102.

https://doi.org/10.1016/j.forsciint.2016.09.007

[2] Ramaekers JG, Moeller MR, van Ruitenbeek P, Theunissen EL, Schneider E, Kauert G. Cognition and motor control as a function of $\Delta^{9}$-THC concentration in serum and oral fluid: limits of impairment. Drug and Alcohol Dependence. 2006 Nov; 85(2): 114-22. https://doi.org/10.1016/j.drugalcdep.2006.03.015

[3] Beaulieu P. Toxic effects of cannabis and cannabinoids: Animal data. Pain Res Manage.

2005; 10(Suppl A): 23A-6A.

https://doi.org/10.1155/2005/763623

[4] Impaired Driving Laws. Government of Canada, Department of Justice, Electronic Communications. 2019 [cited 2019 Dec 27]. Available from: https://www.justice.gc.ca/eng/cjjp/sidlrlcfa/?fbclid=I wAR3mpnyzCrfTM2acTM8vswoeSERSUW_lkMyq2 roTtFFILIMBf71CtbmSQI

[5] Impaired driving investigations. Royal Canadian Mounted Police. 2018 [cited 2018 Oct 21]. Available from: http://www.rcmp-grc.gc.ca/ts-sr/aldr-id-cfa-aldr-eng.htm

[6] Draeger DrugTest 5000. Draeger. [cited 2018 Oct 21].

Available from: https://www.draeger.com/enus ca/Applications/Products/Alcohol-and-DrugTesting/Drug-Testing-Devices/DrugTest-5000

[7] Gjerde H, Clausen GB, Andreassen E, Furuhaugen H. Evaluation of Dräger DrugTest 5000 in a naturalistic setting. Journal of analytical toxicology. $2018 \mathrm{Feb}$; 42(4): 248-54. https://doi.org/10.1093/jat/bky003

[8] Legislative Services Branch. Blood Drug Concentration Regulations. Justice Laws Website. 2019 [cited 2019 Dec 23]. Available from: https://laws-lois.justice.gc.ca/eng/regulations/ SOR-2018-148/page-1.html

He et al. | URNCST Journal (2020): Volume 4, Issue 3 DOI Link: https://doi.org/10.26685/urncst.177
[9] Wille SMR, Raes E, Lillsunde P, Gunnar T, Laloup M, Samyn N, Christophersen AS, Moeller MR, Hammer KP, Verstraete AG. Relationship between oral fluid and blood concentrations of drugs of abuse in drivers suspected of driving under the influence of drugs. Therapeutic drug monitoring. 2009 Aug; 31(4): 511-9. https://doi.org/10.1097/FTD.0b013e3181ae46ea

[10] de Faubert Maunder MJ. The Rapid Detection of Drugs of Addiction. Medicine, Science and the Law. 1974 Oct; 14(4): 243-9.

https://doi.org/10.1177/002580247401400404

[11] Maunder MJ de F. Two simple colour tests for cannabis. United Nations Office on Drugs and Crime. [cited 2018 Oct 25]. Available from: https://www.unodc.org/unodc/en/data-andanalysis/bulletin/bulletin_1969-01-01_4_page006.html

[12] dos Santos NA, Souza LM, Domingos E, França HS, Lacerda Jr V, Beatriz A., et al. Evaluating the selectivity of colorimetric test (Fast Blue BB salt) for the cannabinoids identification in marijuana street samples by UV-Vis, TLC, ESI (+) FT-ICR MS and ESI (+) MS/MS. Forensic Chemistry. 2016 Aug; 1: 13-21. https://doi.org/10.1016/j.forc.2016.07.001

[13] Kelly JF, Addanki K, Bagasra O. The non-specificity of the Duquenois-Levine field test for marijuana. The Open Forensic Science Journal. 2012 Feb; 5: 4-8. https://doi.org/10.2174/1874402801205010004

[14] Fedirko NV, Kruglikov IA, Kopach OV, Vats JA, Kostyuk PG, Voitenko NV. Changes in functioning of rat submandibular salivary gland under streptozotocin-induced diabetes are associated with alterations of $\mathrm{Ca}^{2+}$ signaling and $\mathrm{Ca}^{2+}$ transporting pumps. Biochimica et Biophysica Acta (BBA)-Molecular Basis of Disease. 2006 Mar; 1762(3): 294-303. https://doi.org/10.1016/j.bbadis.2005.12.002

[15] Langel K, Gjerde H, Favretto D, Lillsunde P, Øiestad EL, Ferrara SD, Verstraete AG. Comparison of drug concentrations between whole blood and oral fluid. Drug Testing and Analysis. 2014 May; 6(5): 461-71. https://doi.org/10.1002/dta.1532

[16] Chu MHC, Drummer OH. Determination of $\Delta^{9}$-THC in whole blood using gas chromatography-mass spectrometry. Journal of Analytical Toxicology. 2002 Nov-Dec; 26(8): 575-81. https://doi.org/10.1093/jat/26.8.575

[17] Huestis MA, Cone EJ. Relationship of $\Delta^{9}$-tetrahydrocannabinol concentrations in oral fluid and plasma after controlled administration of smoked cannabis. Journal of Analytical Toxicology. 2004 Sep; 28(6): 394-9. https://doi.org/10.1093/jat/28.6.394

[18] Samyn N, van Haeren C. On-site testing of saliva and sweat with Drugwipe and determination of concentrations of drugs of abuse in saliva, plasma and urine of suspected users. International Journal of Legal Medicine. 2000 May; 113: 150-4. https://doi.org/10.1007/s004140050287 
UNDERGRADUATE RESEARCH IN NATURAL AND CLINICAL SCIENCE AND TECHNOLOGY (URNCST) JOURNAL Read more URNCST Journal articles and submit your own today at: https://www.urncst.com

\section{Article Information}

Managing Editor: Jeremy Y. Ng

Peer Reviewers: Bi-ru Amy Yeung, Jennifer Williams

Article Dates: Received Jan 07 20; Accepted Feb 23 20; Published Mar 2320

\section{Citation}

He A, Nysten M, Rahman F, Wu J. Developing a Method to Determine Salivary THC Concentration. URNCST Journal. 2020 Mar 23: 4(3). https://urncst.com/index.php/urncst/article/view/177

DOI Link: https://doi.org/10.26685/urncst.177

\section{Copyright}

(C) Alina He, Marina Nysten, Farida Rahman, Joyce Wu (2020). Published first in the Undergraduate Research in Natural and Clinical Science and Technology (URNCST) Journal. This is an open access article distributed under the terms of the Creative Commons Attribution License (https://creativecommons.org/licenses/by/4.0/), which permits unrestricted use, distribution, and reproduction in any medium, provided the original work, first published in the Undergraduate Research in Natural and Clinical Science and Technology (URNCST) Journal, is properly cited. The complete bibliographic information, a link to the original publication on http://www.urncst.com, as well as this copyright and license information must be included.

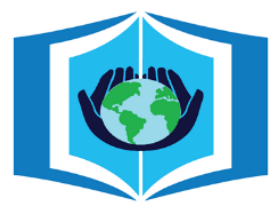

\section{URNCST Journal}

"Research in Earnest"

\section{Funded by the \\ Government \\ of Canada}

\section{Canadà̀}

Do you research in earnest? Submit your next undergraduate research article to the URNCST Journal!

| Open Access | Peer-Reviewed | Rapid Turnaround Time | International |

| Broad and Multidisciplinary | Indexed | Innovative | Social Media Promoted |

Pre-submission inquiries? Send us an email at info@urncst.com | Facebook, Twitter and LinkedIn: @URNCST

Submit YOUR manuscript today at https://www.urncst.com! 